Article

\title{
Higher Education Learning How to Protect the Environment
}

\author{
Hen Friman ${ }^{1, *}$, Netser Matsliah ${ }^{1}$, Yafa Sitbon ${ }^{2}$, Ifaa Banner ${ }^{3}$ and Yulia Einav ${ }^{1,4}$ \\ 1 Faculty of Engineering, HIT—Holon Institute of Technology, Holon 5810201, Israel; netserm@hit.ac.il (N.M.); \\ yulia_e@hit.ac.il (Y.E.) \\ 2 Dean of Students Office, HIT_Holon Institute of Technology, Holon 5810201, Israel; yafasit@hit.ac.il \\ 3 Director of “Israeli Hope", HIT_Holon Institute of Technology, Holon 5810201, Israel; ifaab@hit.ac.il \\ 4 Dean of Students, HIT-Holon Institute of Technology, Holon 5810201, Israel \\ * Correspondence: henf@hit.ac.il; Tel.: +972-3-502-6695
}

Received: 3 September 2020; Accepted: 15 October 2020; Published: 19 October 2020

check for updates

\begin{abstract}
Israeli Hope in Academia" is a program, designed by the president of the state of Israel, Reuven Rivlin. The program is based on the perception that Israeli society is changing, from having a clear majority and several minorities to a society comprised of four principal sectors that are roughly similar in size: secular Jews, religious Jews, Haredi (ultra-orthodox) Jews and Arabs. The program acts to encourage a more diverse and culturally competent higher education system that promotes partnership. One of the means to achieve that goal is to create meaningful educational interactions between people from academia and the younger generation of these sectors. Over the past year, students from various faculties in the Holon Institute of Technology (HIT) took part in a course called "Green Ambassadors", which corresponds with the "Israeli Hope" program. This course was considered an action learning course, which is a course that combines academic learning and social involvement that has an impact on the community. In order to illustrate the environmental topics and to achieve high participation levels of the pupils, the students created a mobile laboratory containing experiments and demonstrations in which the pupils took an active part. Thus, the course managed to make a significant impact on the community and achieve the goals set by the "Israeli Hope" program. This paper presents the "Israeli Hope" program, HIT and the "Green Ambassadors" course, as well as the methodology used to achieve the course's goals. Finally, this paper will discuss the success levels of the course.
\end{abstract}

Keywords: environmental education; elementary school; experimental learning; renewable energy; energy efficiency

\section{Introduction}

The Holon Institute of Technology (HIT) is an academic institution of higher education. Established in 1969, it was originally part of Tel Aviv University (TAU) and became an independent public academic institution of higher education in 1999. HIT trains the next generation of scientists, engineers, designers and technology managers. Fully accredited by the Israeli Council for Higher Education (CHE), it is entitled to grant undergraduate (Bachelor) and graduate (Master) degrees.

HIT's academic body is composed of over 150 professional and experienced (senior) lecturers and researchers. They nurture tight connections with the industry, develop innovative teaching technologies and are extensively involved in the community. These extensive collaborations are embedded in up-to-date course materials and workshops. Industry experts give lectures and tutor HIT's 4500 students. 
HIT trains highly qualified students in the realms of sciences, engineering, digital medical technologies, computer science, technology management, learning technologies and design and plays an important role in their integration upon graduation into key positions within the industry.

The faculty of engineering at HIT is one of the largest producers of electrical engineers in Israel. One of the fields taught in the engineering faculty is Renewable Energy and Power Systems. The Renewable Energy and Smart Grid Excellence Center serves as an information center for elementary school pupils and other groups in the community and provides a platform for enriching the students' knowledge of green energy and the future of the electrical grid. The excellence center provided the theoretical material for the "Green Ambassadors" course, described below.

The students at HIT come from all over Israel and from all sectors-men and women; Jews and Arabs; secular and religious. The collaboration of HIT with "Israeli Hope in Academia" increased the accessibility of the institution and enabled Haredi, Arab, Druze and Circassian students to integrate into academic studies [1].

\section{Israeli Society}

The diversity of Israel's population is incredible. At first glance, one can identify the obvious Jewish majority and Arab minority, but the reality is actually far more interesting. Jewish society consists of three sectors, each having a separate education system: The first is a sector of people on the religious range between secular and "keeping tradition"; the second group is made up of religiously observant Jews; the third, of Haredi Jews-strictly orthodox Jews, who can also be divided into many subsectors but, in general, avoid modernity and adhere strictly to Jewish Law. The Arab society also consists of different groups, with Muslim and Christian being a distinct division [1].

Distinguishing between the different minorities and majority was very clear in the 1990s, especially when examining the population of school pupils. In 1995, 51\% of elementary school pupils were secular Jews, $16 \%$ were religious Jews, $11 \%$ were Haredi Jews and 22\% were Arab. Three decades later, that clear distinction is no longer possible. By 2018, the ratio of Haredi Jews had increased dramatically to $23 \%$ and the ratio of secular Jews in elementary school shrunk to merely $39 \%$. The percentage of religious Jews lowered slightly to $14 \%$ and the Arab sector grew slightly to $24 \%$ [2].

This new ratio of sectors makes the population appear less like a majority group with a few minorities and more like four relatively equal-sized societies in Israel. However, the difference in socio-economic status between these societies remains very clear. The secular and religious societies dominate the upper and middle classes of Israel, while the lower class is mostly comprised of Haredi Jews and Arabs. In 2017, the median income of an Arab household was NIS 11,435, while the median income of a Jewish household was NIS 19,140 [3]. In the Jewish society, the average income of a Haredi household was NIS 13,658, with NIS 3191 of it coming from welfare, while the average income of secular and religious households was over NIS 21,000, with less than NIS 2200 of it coming from welfare [4].

The relatively poor socio-economic state of the Haredi and Arab societies stems from different reasons. The Haredi society and its education system encourage its men to focus on Bible studies and its women to work and support the family financially while raising the children. In 2016, only $42 \%$ of Haredi men aged 15 years or more were employed, compared to 59\% of Haredi women. In the Arab society, which is generally more traditional than the Jewish population in both religion and gender role division, there is a relatively low participation rate of Arab women in the workforce. In 2016, the employment rate of Arab women aged 15 years or more was $25 \%$, compared to $61 \%$ among Arab men and 64\% among Jewish women [4]. In addition, both Arab and Haredi societies are less likely to matriculate and advance to higher education. In 2016, 50\% of 17-year-old Arabs received a matriculation certificate, compared to $61 \%$ of their Jewish counterparts, including Haredi Jews. In the same year, only $20 \%$ of Arab men and $29 \%$ of Arab women aged 25-34 had 16 years of education or more, compared to $41 \%$ of men and $48 \%$ of women of the same age group in the Jewish population [5]. In the Jewish society, only $33 \%$ of twelfth-grade pupils in Haredi schools took the matriculation exams 
in the 2014-2015 academic year, and only $11 \%$ of the pupils passed them. This is compared to $94 \%$ of pupils in secular and religious schools who took the exams, and $76 \%$ of them passing the exams [6]. The poor rates of high school matriculation and academic education lead both the Arab and Haredi societies to be limited in their work advancement opportunities and their access to high ranking and high paying jobs.

These socio-economic gaps between the sectors in the Israeli population led the president of Israel, Reuven Rivlin, to launch a flagship program, "Israeli Hope". The goal of the program is to establish a sense of partnership between sectors and to create collaboration of sectors in key fields, such as education, academia, employment, local municipality and sport. The program "Israeli Hope" has several subprograms, each targeted at a different aspect of society. "Israeli Hope in Education" promotes joint activities of teachers and pupils from different sectors. "Israeli Hope in employment" promotes employment diversity, with emphasis on integration of the Haredi and Arab sectors in the Israeli workforce. "Israeli Hope in Regional Clusters" deals with developing and intensifying partnership between various communities in each region. "Israeli Hope in Sport" promotes tolerance and deals with violence and racism in Israeli sport. Finally, "Israeli Hope in Academia" promotes a diverse and culturally competent academic world [7].

\section{"Israeli Hope in Academia" and HIT}

The "Israeli Hope in Academia" subprogram set goals in different aspects of academic life. Among these goals is establishing an academic calendar suited for all sectors of society; creating meaningful encounters between people of different backgrounds; adjusting the content and phrasing of exams and tasks to fit the diverse composition of students; establishing communication lines between colleges and student organizations representing different sectors; leveraging the presence of academic institutions in their surrounding community for meaningful educational experiences.

It is the last goal listed above that was the trigger for creating the "Green Ambassadors" course at the Holon Institute of Technology (HIT) [8]. The Social Involvement Unit at HIT aims to encourage meaningful social action in society, as it perceives that these actions influence both society and the academic institute and create a sustainable positive change. The Social Involvement Unit motivates students to take part in action learning courses-courses that combine academic studies with social activities. The active integration of the students in communities, especially those that represent national minorities, inspires social sensitivity and cultivates the values of giving, helping, promoting and respecting differences. The Council for Higher Education in Israel financially supports the action learning courses of the Social Involvement Unit.

\section{Action Learning Course}

An action learning course deals with social challenges, introduces the students to various worldviews and develops pragmatic ideas and the ability to think out of the box. The students are graded and receive credit points for participating in the course. By engaging in active experimental learning, the students can see the connection between what they learn in the classroom and how it translates into the real world [9]. The students engage with social organizations, institutions and state authorities and perform practical work with diverse populations. Through that experience, the students improve their academic abilities, formulate ethical awareness towards their social and environmental reality and see how they can create a positive change in their community [10].

\section{Environmental Issues in Israel}

\subsection{Renewable Energy}

The Ministry of Energy and Water strives to develop and integrate renewable energy in Israel's electricity market. This is due to a government decision to increase resilience of the power production capabilities as well as promote environmental aspects. The trend all around the world is to replace 
fossil fuel energy production with renewable energy production-an energy production that originates from an everlasting source, such as wind, sun radiation, water flow, etc. Government resolution no. 4450 from 2009 set a goal of minimum renewable energy-based electricity production of $10 \%$ of the total electricity production by 2020 , with a preliminary goal of $5 \%$ by 2014 [11]. These goals, however, have not been met-by 2018 , only $2.8 \%$ of Israel's electricity production relied on renewable sources [12]. The reasons for not meeting the goals are mainly regulatory-major restrictions regarding photovoltaic system installation had been lifted only recently, and the field of wind-based production is still heavily restricted by regulation [13]. In 2015, government resolution no. 542 set updated goals of $13 \%$ and $17 \%$ minimum renewable source-based electricity production by 2025 and 2030, respectively [14]. Thus, renewable energy is a topic of top priority to promote.

\subsection{Energy Efficiency}

The state of Israel suffers from lack of electricity supply capabilities at peak hours. An important method to reduce peak consumption and save energy and money is energy efficiency-using less electricity to get the same results. Government resolution no. 542 from 2015 set a goal of reducing electricity consumption by $17 \%$ by 2030 compared to the projected consumption, based on the 2015 consumption trend [14]. Methods for achieving that goal included investing government funds in implementation of newer, more efficient technologies in the industrial sector and public infrastructure; examining a tax relief policy on purchases of energy conserving products; setting standards and incentives for energy efficient construction of residential and commercial buildings [15]. It seems that the measures taken have had a positive effect on the consumption trend-while the total energy consumption rises each year, since 2015, the consumption per capita and consumption per GDP have been consistently declining (Figure 1) [12].

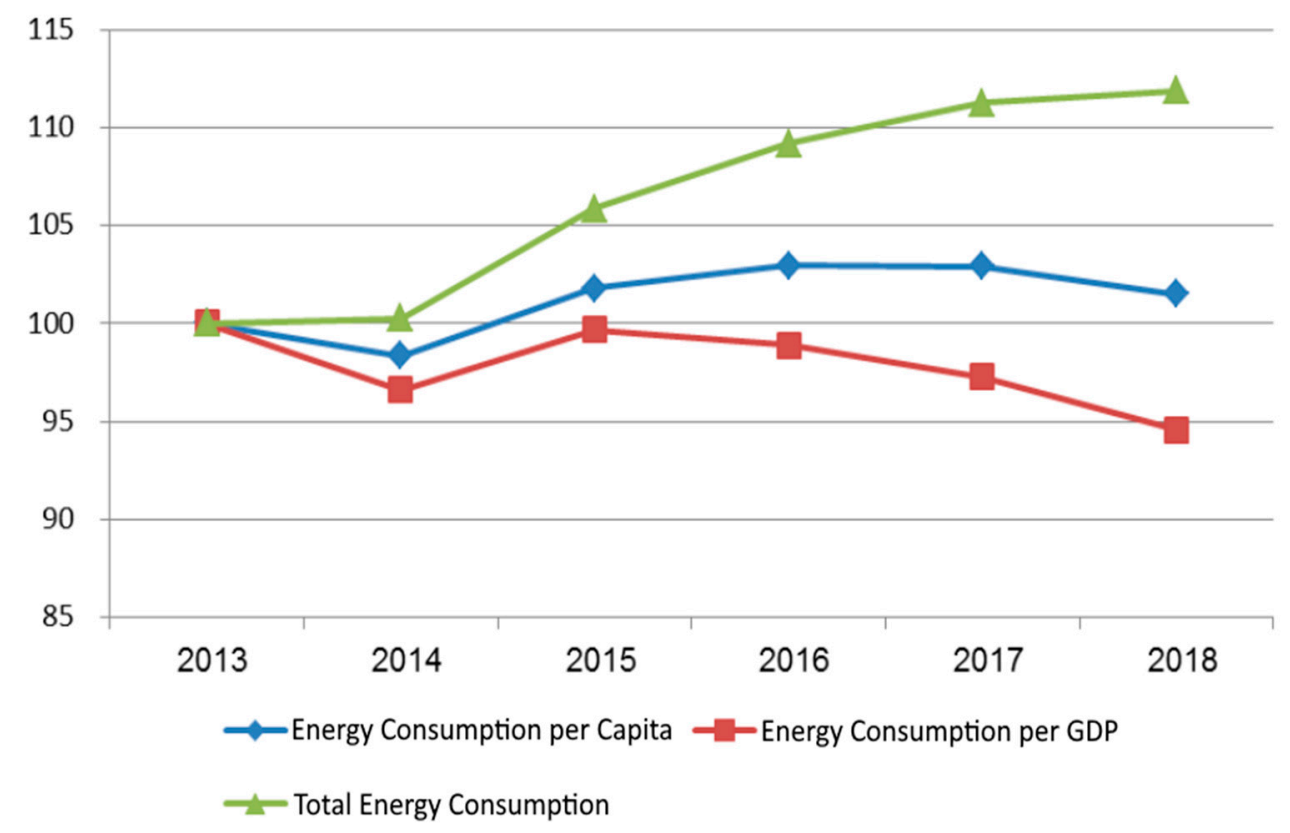

Figure 1. Yearly energy consumption (per capita, per GDP, total). Base $100 \%$-2013. [12].

\subsection{Waste and Recycling}

The yearly waste generation in Israel is estimated at $612 \mathrm{~kg}$ per person-among the highest in the world. This, in addition to the high rate of population increase in Israel (the highest among developed countries), portrays a grim reality of massive waste generation. Handling of generated waste is also lacking in Israel—only 19\% of it is transferred for recycling, while more than $80 \%$ is dumped in landfills. This puts Israel among the worst managers of waste in OECD (Organisation for Economic Co-operation 
and Development) countries. The financial cost of handling waste so ineffectively currently stands at 3.6 billion Israeli shekels per year (about USD one billion). This cost is expected to rise to 6.3 billion shekels by 2030, following the current trend.

The changing compound of the waste is another cause for concern. The percentage of plastic in the waste in Israel rose from $8 \%$ in the 1970 s to $18 \%$ in 2012 and it keeps on rising each year. As waste disintegrates, the plastic components in it are reduced to microplastic-plastic particles of $5 \mathrm{~mm}$ in size or less. These tiny particles find their way to the air, drinking water sources and oceans. As they may contain toxic and carcinogenic substances, microplastic particles pose a threat to both marine and human life.

The main reasons for the unflattering status of Israel in the field of waste and recycling are a lack of long-term strategy and planning by the Israeli Ministry of Environmental Protection, as they change with each elected government; lack of enforcement of waste and recycling related laws; wrong social norms in the population of littering in public spaces, caused by lack of proper environmental education and lack of public trust in the systems responsible for handling waste and recyclable materials [16].

In 2018, the Ministry of Environmental Protection published a new strategic plan for waste treatment by 2030 . The plan includes education and incentives to reduce product consumption, initiatives for reuse of products, education programs for awareness increase of recycling, increased support in waste sorting facilities and construction of three waste-to-energy facilities. The ultimate goal of the plan is to reduce landfill dumping to $26 \%$ of the total waste by 2030 and it is budgeted for four billion shekels [17].

\subsection{Water Pollution}

Israel is located in an area which suffers from a lack of fresh water in nature. Due to this fact, Israel has developed a successful desalination industry in order to supply high quality water to its citizens. However, the threat of water pollution still exists as $20 \%$ of water supply still comes from natural sources. Over decades, natural sources of water have been polluted, mainly by industrial waste generated in industrial facilities, municipal waste intentionally or negligibly spilled from cities into water streams, oil spillage from petrol stations and old oil pipes and over-fertilization of agricultural land [18]. These sources of pollution caused water contamination of immense magnitude in the two main natural water reserves of Israel—the Coastal Aquifer and the Mountain Aquifer. There are over 360 measured water sites that are considered contaminated, most of which are located in the Coastal Aquifer, and they affect an estimated $10 \%$ of the Aquifer's accessible water. As groundwater restoration is not done in most of the contaminated sites, the pollution often spreads into neighboring areas [19].

The Ministry of Environmental Protection works towards reducing further pollution, mainly by setting regulation for pollution prevention methods, monitoring water sites and taking legal action against polluting entities. It also promotes water streams restoration activities [20].

\section{Methodology}

The "Green Ambassadors" course was developed as an experimental learning course [21]. Experimental learning is a type of learning in which meaning is produced out of experimentation and experience. This process happens through involvement, observation and analysis [22]. Experimental learning is a sub-section of experimental education, which is a stream in education philosophy. It refers to the individual process the pupil experiences, while experimental education deals with the whole range of relationships and approaches which facilitate the learning process [23]. The strength of experimental learning is that it occurs in a variety of learning methodologies, such as project-based learning, learning through games, learning through simulation, etc. [24].

Pupils learn best what they feel is relevant to their lives. Studies show that learning is most effective when it is active, goal-driven and personally relevant [25]. Since the search for meaning is embedded in humankind [22], pupils mostly concentrate on the learning tasks they find meaningful. Those who seek to influence pupils learning should try and create the best possible match between the 
goals of the institution and the goals of the learners. With learning by experience, pupils gain valuable knowledge and skills while researching important everyday problems, such as how to decrease environmental pollution in the park close to their home. Meaning, pupils learn when they want to learn. Since acquiring knowledge and skills demands a great effort from the learner, as well as guided practice, and since the level of knowledge acquired is influenced by the will of the learner [25], it is important to create curiosity and interest in the classes.

Many researchers emphasized the role of experience in the learning process, which serves as a basis for the experimental learning model that was published in 1975 by David A. Kolb and Ron Fry. The model includes four elements: a new experience; analysis and insight development based on the personal experience; construction of a theory explaining the experience (either by using prior knowledge or knowledge acquired from the experience itself); examination of the theory in new situations [26]. Kolb and Fry claimed that the learning process can start at any one of the four stages and that one should consider them as an ongoing spiral, but in order for the learning to be meaningful, the learner must go through all of them [27].

The learning process includes two sub-processes: absorbing information and processing information. Therefore, the experimental learning theory requires the learner to possess polar abilities and skills and the learner needs to choose which ones should be used in each situation. Each one of the four stages of the model requires choosing a different learning skill. The learner might excel in theoretical processes but might fail to assess their value. The teacher must recognize, understand and analyze the methods in which the individuals receive and process information and help each learner individually with their difficult spots in the process [28]. The teachers and learners should share their own teaching and learning methods with each other. This sharing will make the learner understand why the subject was chosen to be passed in a certain way by the teacher. Meanwhile, the teacher will be able to identify the different learning methods among the learners, will develop empathy towards them and will, therefore, be able to help them better [27].

Challenging and intriguing teaching involves a deep, active experimental learning which is connected to relevant issues that interest the learner. Performing high-level research in each of the approaches requires use of several thinking strategies. Only when the learners master these strategies can they perform quality research. The research process is often performed in classes in a technical and superficial manner, as the learners go through all the stages of the research but focus on its outer layers and do not go "deep". Therefore, the way to avoid having superficial research is through guided work on thinking strategy development and gradual implementation of them with the learners [28].

Deep, meaningful learning in the field of environmental education is discussed in the ecocentric philosophy-a perspective that perceives nature not as a service provider for the human species but as an equal to it, if not more important. Ecocentrism claims that the drive to protect the environment should come from the human capacity for compassion, rather than the sense of nature's value to self. In a paper written by David Molina-Motos and published in 2019, it is suggested that ecocentric environmental education should reconceptualize the traditional, human-focused concepts of environmental education without denying them, as they still hold value. The emphasis should rather be on developing the awareness that humans are one species among all species on Earth, as well as cultivating the unique human trait of compassion [29]. This compassionate approach towards conservation stems from nonhuman personhood-the notion that all sentient beings are equal and, therefore, deserve the same respect and rights as humans. It counters the traditional notion of human exceptionalism, in which humans are regarded as "of a categorically separate and higher moral status than all other species".

However, since the "Green Ambassadors" program involved teaching pupils as young as 6, since awareness to environmentalism in different sectors is not equal and since the amount of sessions and their duration were very limited, it was decided to keep the approach towards environmental education more personal and relevant to the pupils' everyday lives, i.e., human-focused. Teaching by the ecocentric approach would have required extensive groundwork on the perception and connection of the pupils with nature before discussing any environmental issues. Therefore, the depth desired 
for the pupils' learning process was aimed to be achieved by making it a unique, meaningful, long-term, impactful experience. It was implemented by sharing personal life experiences which involved environmental issues, by linking environmental issues to the pupils' quality of life and by conducting experiments that demonstrated them, thus making the course an experimental learning one, as mentioned above. The experiments of each topic are described in Section 5 below.

\section{Implementation-“Green Ambassadors" Course}

The course had two main goals- to introduce HIT's students to different societies in Israel and to make elementary school pupils more aware of environmental issues.

In 2016, the "Green Ambassadors" pilot program took place in a secular elementary school in the city of Holon. In 2017, in fulfillment of the "Israeli Hope in Academia" vision, the course was run in an Arab elementary school in Ramla. The students of HIT established ties with Arab society and expanded the children's knowledge of environmental issues [21]. The third "Green Ambassadors" course was held in 2018 at a Jewish religious school in Holon.

From March 2019 until June 2019, the course was again run at an Arab school, this time in the city of Lod. In 2020, the course operated under gender segregation in Ultra-orthodox (Haredi) schools-“Bnei Menachem" school for boys and "Bnot Menachem" school for girls—between October 2020 and February 2020 in Holon.

Overall, since the formulation of the course in 2016, over 200 students have taken part in it. The students came from all sectors of Israeli society (secular, religious, Haredi, Arab) and various socio-economic backgrounds. They arrived from all of HIT's faculties in fairly equal numbers - electrical engineering, industrial engineering, design, computer sciences and instructional design. As for the pupils, over 700 pupils have gone through the program, with ages ranging from 6 to 13 years old.

In the frontal part of the course, the students were introduced to the Israeli society and knowledge on environmental issues-renewable energy, energy efficiency, waste and recycling and water pollution. The students learned how they can produce fun activities to deliver the principles of each subject and then they were divided into work groups, each handling a single subject. In the practical part of the course, each group planned, purchased and built experiment workshops which demonstrated the principles of the subjects. Then, the groups went to the school and taught the material using the workshops. Before each lesson, the pupils were given a multiple-choice questionnaire in order to estimate their initial level of knowledge. When the activity was complete, the pupils were given the same questionnaire, this time in order to see the progress in knowledge achieved by the lesson, compared to the pupils' initial knowledge.

\section{Environmental Content and Teaching Practices}

Each lesson began with a quick introduction to the issue discussed, followed by a set of unique activities described below.

\subsection{Renewable Energy}

The group of students who built the "renewable energy" lesson divided the lesson into three parts. In the first part, the electrical generator was introduced and so was the physical concept behind its work. As a demonstration for its operation, the pupils were given a toy generator which converted a handle rotation movement by hand into electricity and powered up a light bulb. In the second part, alternative methods of rotating the generator were discussed, including the usage of water and air flow. As a demonstration, the students brought a self-built hydro-electric station and miniature wind turbines and the pupils played with them and saw how they produce energy. In the last part, the photovoltaic effect was taught, and then the pupils were given solar-powered toy cars, and they conducted a race using light sources to move the cars. 


\subsection{Energy Efficiency}

The group of students who built the "energy efficiency" lesson created four experiments to demonstrate the principal. The first experiment dealt with water heating. The pupils were asked to fill up three identical electric kettles with enough water for two cups of tea (Figure 2a). They chose three different portions of water, and were asked which kettle would make the water boil first and which one would consume the most energy. While the water was boiling, the students explained why a larger portion of water requires more time and energy to boil. They also showed that it is possible to get an exact amount of water needed by pouring the water to the cups for measurement and then to the kettle for boiling.

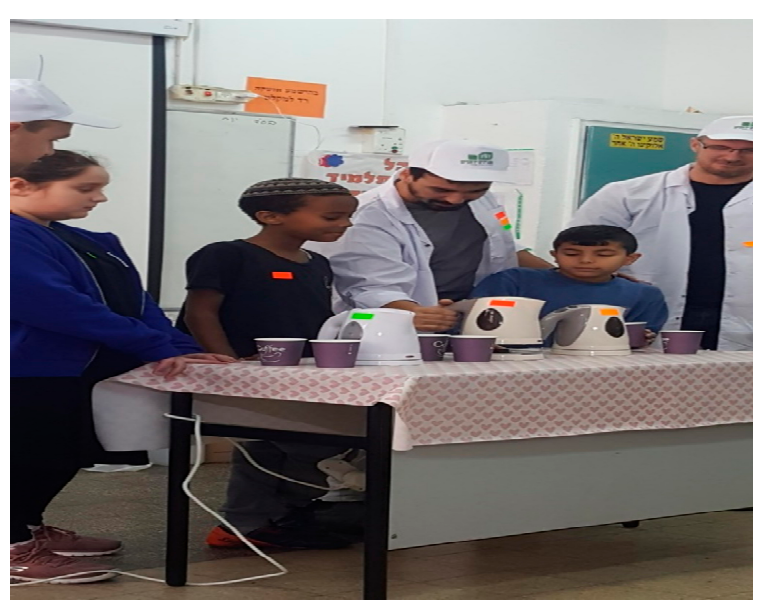

(a)

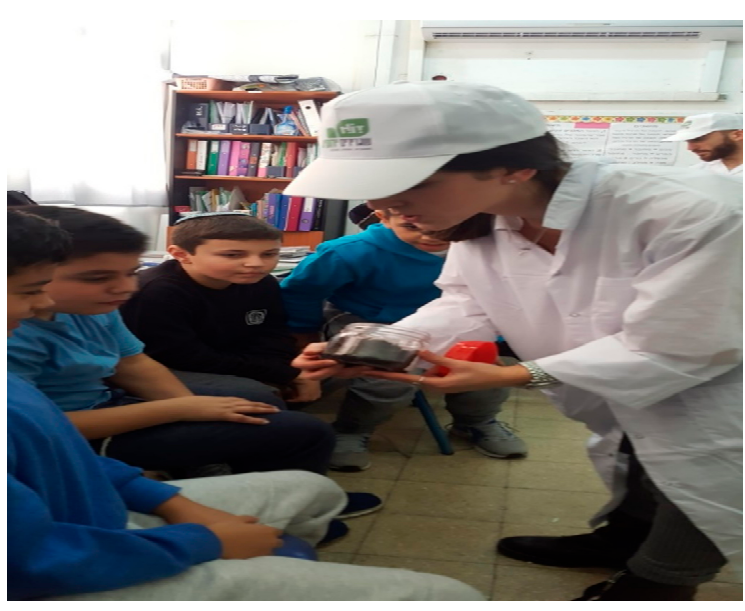

(b)

Figure 2. (a) Water heating experiment in the "energy efficiency" lesson. (b) Pupils are given a personal compost jar at the "waste and recycling" lesson.

The second experiment dealt with thermal insulation. The students poured the boiled water from the kettles into two vials, one with a wooden thermal coating and the other without it. The pupils took temperature measurements ten minutes later and saw that the thermal insulated water's temperature was higher than that of the non-insulated water by $10^{\circ} \mathrm{C}$. Thus, the pupils witnessed and understood the importance of using thermal insulating materials for energy conservation.

The third experiment dealt with lighting efficiency. The students presented two types of lighting sources-a halogen lamp and a LED light. They connected each light to an identical power bank in the form of charged capacitors. Turning on the lights, the pupils could see that while both lights reached the same luminosity levels, the halogen lamp drained all the power given to it within less than a minute and the LED light continued to work for several minutes. By witnessing the difference in performance, the pupils understood how importance of replacing old and wasteful methods of lighting with new, cost-effective ones.

The fourth and final experiment of the lesson dealt with harnessing technology to increase energy efficiency. The students presented two image projectors-one turned on during the entire lesson and the other connected to a motion sensor that turned it on only when there was a movement in its proximity. Using the projectors, the students demonstrated how using existing technology can help in reducing unnecessary power consumption in everyday tasks, such as home and garden lighting.

\subsection{Waste and Recycling}

The students of the "waste and recycling" group wanted to explain and show the difference between organic waste, which can be decomposed and return to nature, and non-organic waste, which contains a group of chemical substances of mineral origin and can be reused. 
The first activity involved teaching the pupils about the different types of recyclable materials and their appropriate recycling bins. The pupils then went out of the class and had a "recycling race" in the hallway, in which they needed to beat their friends in sorting a pile of recyclables and putting each recyclable in the correct bin. The second activity involved material separation. The students demonstrated how to separate plastic from sand, iron from sand and Styrofoam from sand.

At the end of the lesson, the pupils received a small personal compost jar, containing organic waste and two earthworms. The students explained how the worms decompose the waste and turn it into a rich fertilizer. The jars had a label with instructions on how to take care of the worms, how to feed them and how to maintain the jar (Figure 2b).

\subsection{Water Pollution}

The group of students in charge of this subject wanted to demonstrate how easily water can be contaminated and how difficult it is to make contaminated water usable again.

The first activity of the lesson was a game of "confession" — sentences confessing of littering were projected on a screen and the pupils who admitted committing the actions stepped forward. The confessing students read aloud a fact connecting the littering action to water pollution and then threw plastic bags, chewing gum and food coloring into a water tank, linking their littering action in the past to the polluted water in front of them.

The second activity was a demonstration of purifying the polluted water. The pupils, with the assistance of the students, built a water filter. The filter was made by putting gravel, cotton wool and activated coal in a holed bottle. The students poured the polluted water into the bottle, and the pupils saw how the gravel and wool blocked the large contaminators, and the coal filtered the food color. Through the holes on the other side of the bottle came clean and clear water. However, it took longer than half an hour for the process to clean only a small amount of water from the tank, while contaminating the whole tank took a few seconds.

At the end of the lesson, the pupils built a miniatured version of the water filter and connected it to a keychain which they received as a gift (Figure 3).

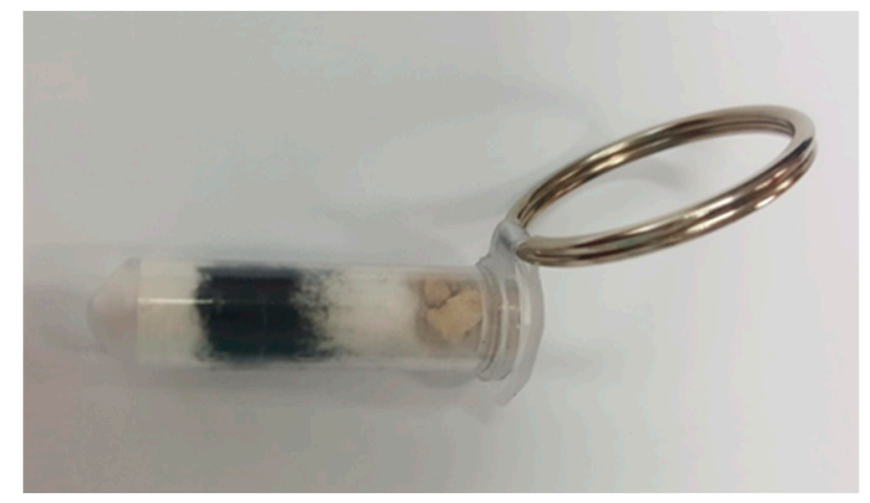

Figure 3. A miniature water filter on a keychain.

\section{Results}

Quantitative measures were largely used to determine the success of the course.

Trivia quizzes were conducted at the beginning and end of each lesson. This was used to determine how well the pupils retained the new information. In an effort to make the quizzes fun and lighthearted, a "Kahoot!" platform trivia game was used (Figure 4). 


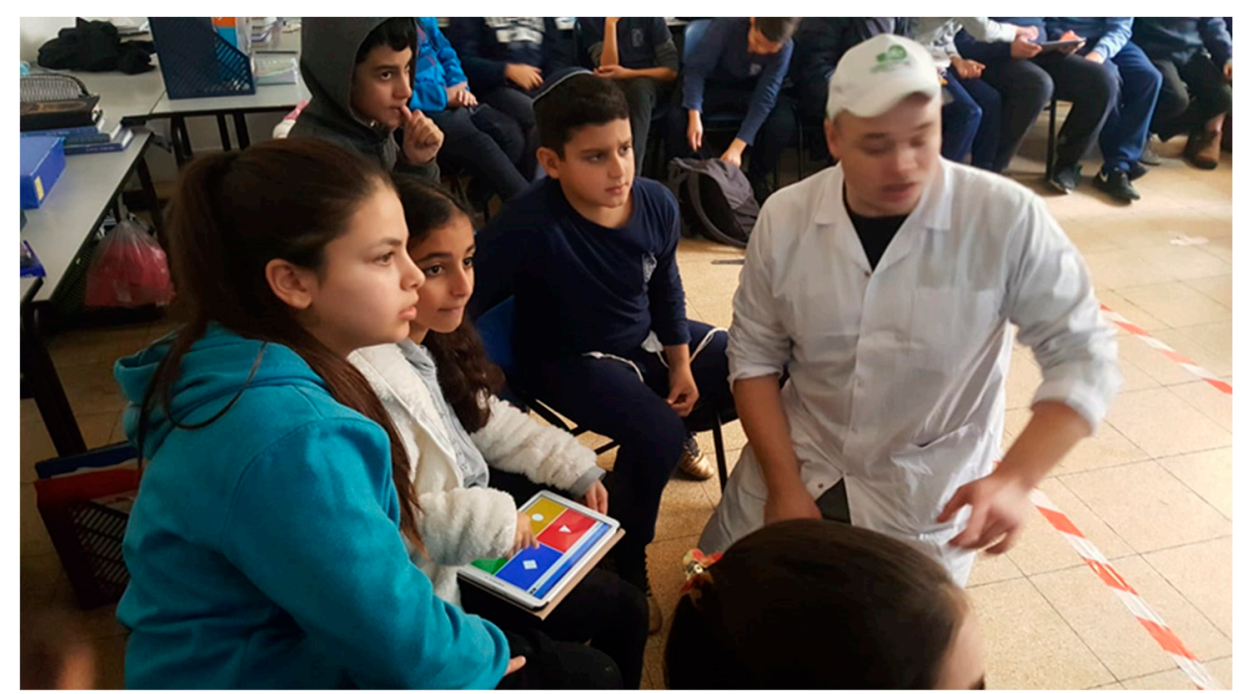

Figure 4. Pupils answering the "Kahoot!" trivia questions.

At the start of the lesson, the children were given five quiz questions. They either guessed the answers or used previous knowledge. At the end of the lesson, the questions were repeated and the children used their new knowledge to confidently answer them.

For example, when asked what types of energies can be generated from the sun, in the trivia questions before the lesson, about $50 \%$ of the pupils in the various secular, religious and Arab societies knew the correct answer. In the Haredi (ultra-Orthodox) society, only about $20 \%$ knew the answer. However, following the lesson, about $80 \%$ of the pupils learned and knew the correct answer, especially in the Haredi (ultra-Orthodox) group who started without prior knowledge. After the lesson, $90 \%$ of the pupils seemed to choose the correct answer (Figure 5).

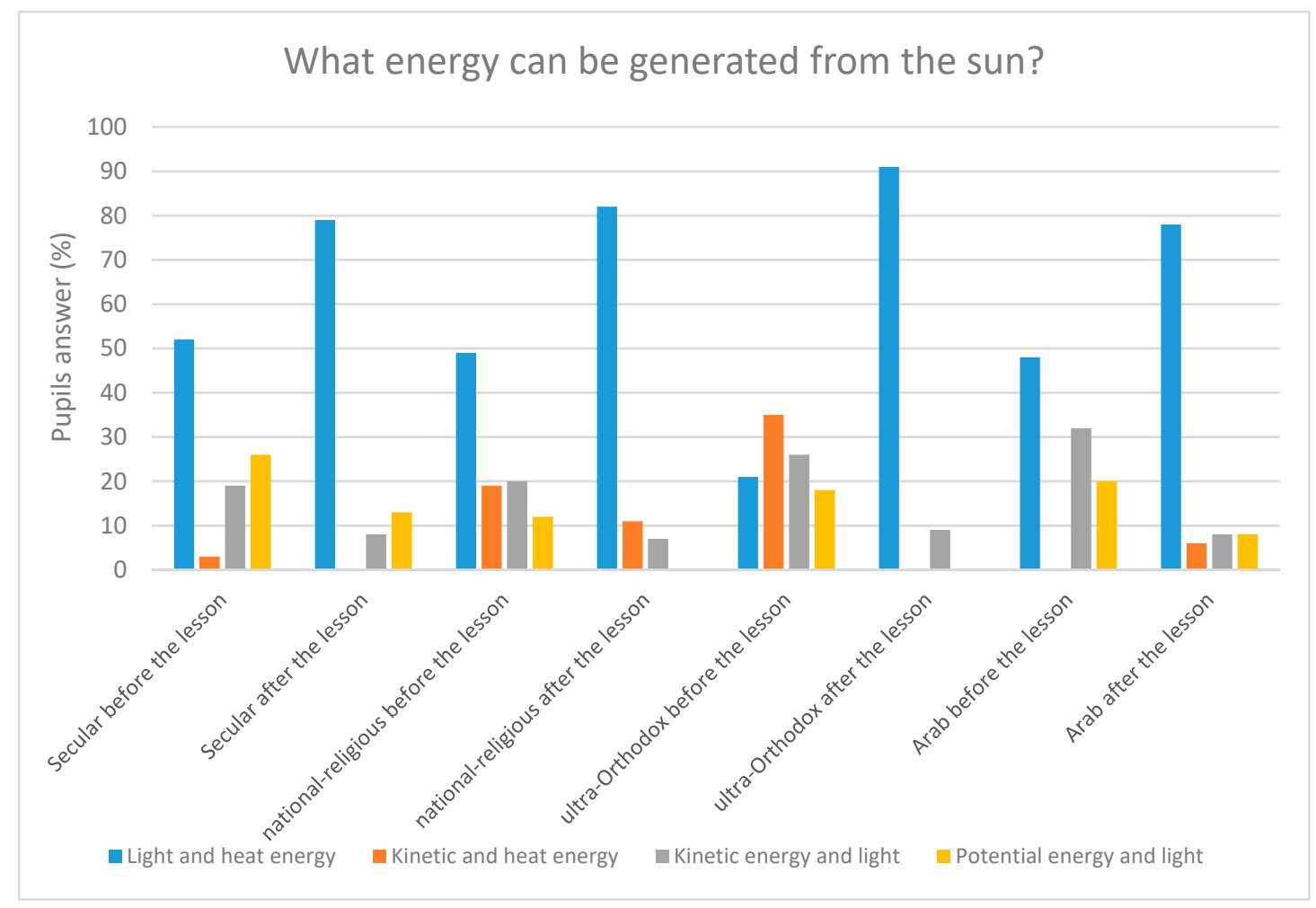

Figure 5. Distribution of answers to a trivia question. 
In order to examine the school staff's levels of satisfaction with the course, the HIT lecturers created and distributed surveys. The teachers provided information on the children's levels of participation, understanding and enjoyment. The teachers also stated their own level of satisfaction from the lesson and gave feedback for improvements to future courses.

The teachers' feedback reports provided an even better tool of examining the whole learning process. As the pupils' direct authority and closest people in the school staff, they were able to observe and accurately analyze different aspects of the lessons. In the report, they wrote what key subjects were taught in the lesson and how the fact that academy students taught them contributed to the learning process. They gave constructive notes for improvement, as well as marking their estimation of the pupils' levels of interest, participation, understanding and enjoyment, in a 1-to-5 ranking scale (Figure 6). As an example, in a report of the "waste and recycling" lesson, one teacher wrote that the experiments helped deliver the concept of the issue and suggested to "start the lesson with a short video, and only then to follow with a conversation", in order to better introduce the issue to the pupils.

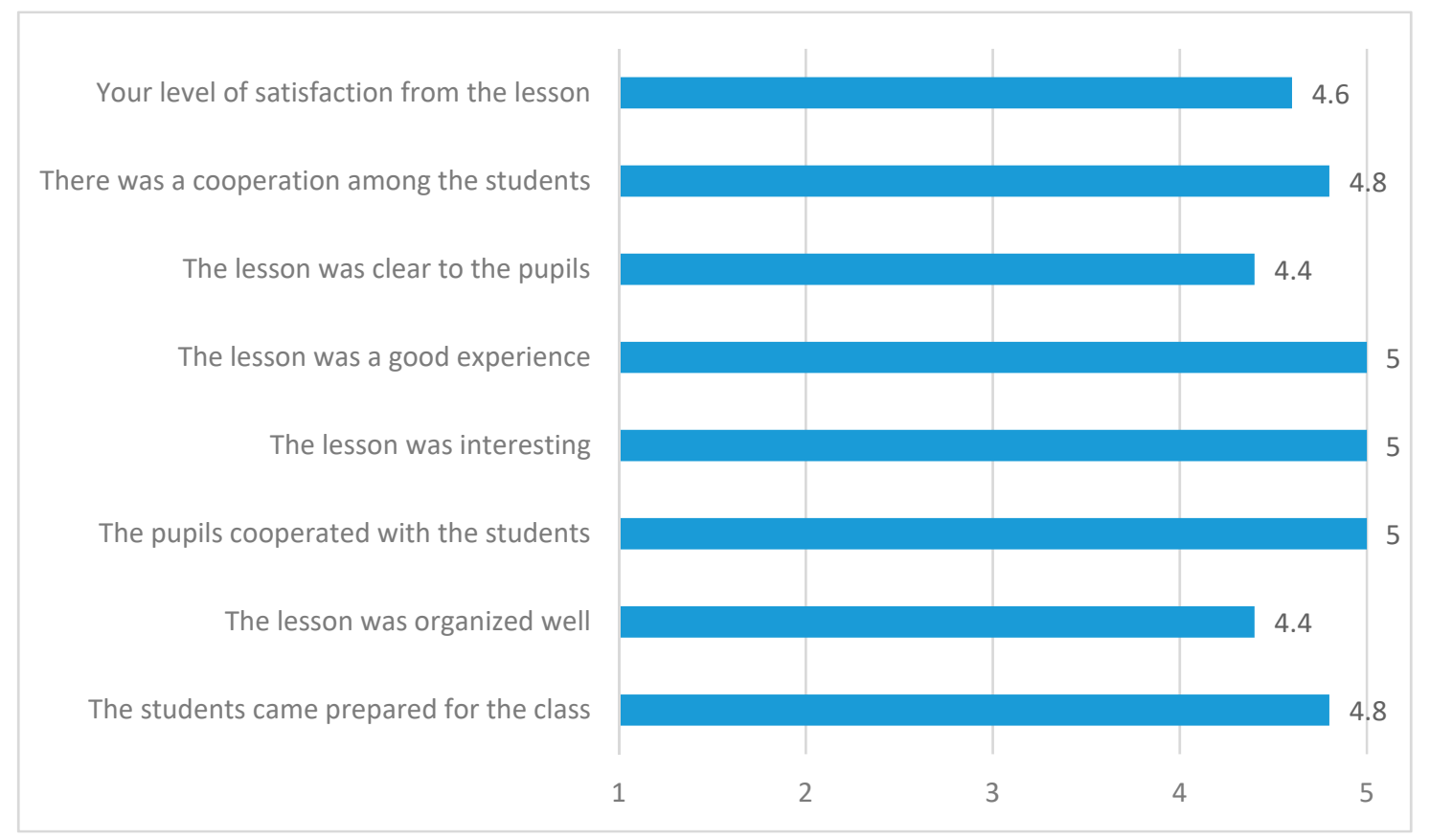

Figure 6. Lessons average marks, given by the school teachers.

Finally, the students' feedback meeting and reports gave a fascinating insight on their experience studying the course. They sensed and appreciated the fact that it was an action-learning course in which they were actively involved and could express their abilities for the benefit of the community. Several students, especially from the secular sector, expressed how meaningful the encounter with a different society to their own was for them, as they were exposed to previously unfamiliar aspects of Israeli life. They gave constructive notes for improvement for future "Green Ambassadors" courses, and said they would recommend the course to their friends. The students marked the various aspects of the course in a 1-to-6 ranking scale (Figure 7). 


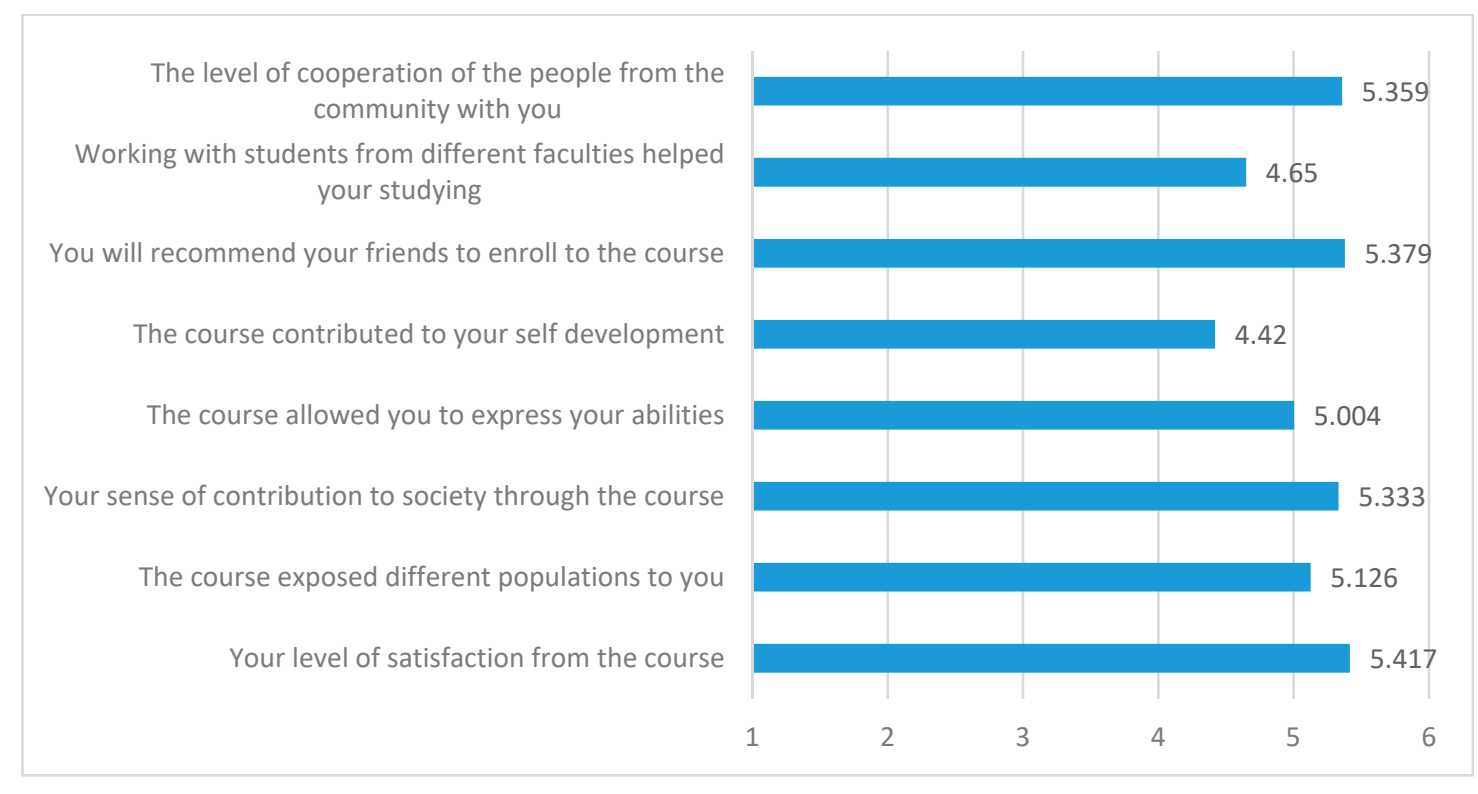

Figure 7. "Green Ambassadors" course average marks, given by the students.

\section{Conclusions}

The "Green Ambassadors" program proved to be a successful method for HIT and its students to achieve the goals of "Israeli Hope in Academia". The course strengthened ties between the institute and the community surrounding it and exposed the students to various sectors. Furthermore, as an experimental-learning course, "Green Ambassadors" helped the students transform their acquired knowledge of environmental issues into meaningful educational experiences for the pupils at the schools.

The trivia questions given to the pupils proved to be a useful method for determining the effectiveness of each lesson. The pupils learned through the activities and answered the questions of the final tests with a much higher success rate compared to their initial quiz at the beginning of the lesson.

The feedback reports from the teachers showed that the students participated enthusiastically and enjoyed the program. The staff at HIT took into consideration the teachers' suggestions for improvement and made changes accordingly for the next round of the course.

The HIT students' feedback meeting and reports substantiated the success of the "Green Ambassadors" course. The reports showed that they enjoyed the experience and that they sensed that they were making a positive change in the community. However, it has been stated multiple times throughout the years that the students found scheduling planning meetings with other students from different faculties problematic. The different schedules of the faculties led to students being unable to mix sufficiently. At times, there were students from only one faculty developing a lesson.

Future plans for the "Green Ambassadors" course include revisiting classes that were taught in the past in order to assess how much of what they learned in the lesson they can still recall. This will provide a good indicator for the long-term influence level of the program on future generations. In addition, since the COVID-19 pandemic restrictions prevent the course from taking place in its current form, the plan for 2020-2021 is to send each pupil a personal experiment kit. The students will teach and guide the pupils via online video chat (e.g., Zoom) and the pupils will conduct the experiments at home. This should provide an interesting comparison between experiencing the course as part of a group and experiencing it individually.

Author Contributions: H.F., N.M., I.B., Y.S. and Y.E. conceived and designed the experiments; H.F. and I.B. performed the experiments; H.F. and N.M. analyzed the data; H.F., N.M. and I.B. wrote the paper. All authors have read and agreed to the published version of the manuscript. 
Funding: This research was funded by the Higher Education Council and the Social Involvement Unit at HIT.

Conflicts of Interest: The authors declare no conflict of interest.

\section{References}

1. Economy \& Budgeting Administration, Ministry of Education. Selected Data for 2018 (Hebrew Only). Israel. Available online: http://meyda.education.gov.il/files/MinhalCalcala/NetunimTashahh.pdf (accessed on 12 August 2018).

2. Shafir, M.; Yagur-Carrol, A. Indices of Quality of Life, Sustainability and National Resilience 2017. National Bureau of Statistics. Israel. (Hebrew Only); 2019. Available online: https://www.cbs.gov.il/he/Statistical/ statistikal-174.pdf (accessed on 8 April 2017).

3. National Bureau of Statistics. Society in Israel—Religion and Self-Definition of Level of Religiosity, Report No. 10. Israel. (Hebrew Only). Available online: https://www.cbs.gov.il/he/publications/DocLib/2018/rep_10/ h_print.pdf (accessed on 6 June 2018).

4. Myers-JDC-Brookdale. The Arab Population in Israel: Facts \& Figures 2018. Israel. Available online: https://brookdale.jdc.org.il/wp-content/uploads/2018/03/MJB_Facts_and_Figures_on_the_Arab_ Population_in_Israel_2018-English.pdf (accessed on 10 September 2018).

5. Cahaner, L.; Malach, G.; Choshen, M. Statistical Report on Ultra-Orthodox (Haredi) Society in 2017. The Israel Democracy Institute. Israel. 2018. Available online: https://en.idi.org.il/media/10441/statistical-reporton-ultra-orthodox-society-in-israel-2017.pdf (accessed on 3 March 2017).

6. "Israeli Hope" Website. Available online: https://www.israeli-hope.gov.il/en (accessed on 4 June 2015).

7. Friman, H.; Matsliah, N.; Beck, Y. Renewable Energy Lab at the Faculty of Electrical Engineering. In Proceedings of the 10th Annual International Technology, Education and Development Conference, Valencia, Spain, 7-9 March 2016; pp. 2311-2318.

8. Arar, K. Israeli education policy since 1948 and the state of Arab education in Israel. Ital. J. Sociol. Educ. 2012, 4, 113-141.

9. Reddan, G.; Rauchle, M. Student perceptions of the value of career development learning to a work-integrated learning course in Exercise Science. Aust. J. Career Dev. 2012, 21, 38-48. [CrossRef]

10. Israeli Government Secretariat. Government Resolution no. 4450 (Hebrew Only). Israel; 2009. Available online: https://www.gov.il/he/Departments/policies/2009_des4450 (accessed on 9 September 2017).

11. National Bureau of Statistics. Energy Balance of Israel 2018 (Hebrew Only). Israel; 2020. Available online: https://www.cbs.gov.il/he/mediarelease/DocLib/2020/003/03_20_003b.pdf (accessed on 25 January 2020).

12. Bank of Israel. The Development of the Electricity Market in Israel: Toward a Sustainable Electricity Market. Israel. 2017. Available online: https://www.boi.org.il/en/NewsAndPublications/PressReleases/Pages/27-9-17. aspx (accessed on 9 September 2017).

13. Israeli Government Secretariat. Government Resolution no. 542 (Hebrew Only). Israel; 2015. Available online: https://www.gov.il/he/Departments/policies/2015_dec542 (accessed on 30 September 2017).

14. Israeli Government Secretariat. Government Resolution no. 1403 (Hebrew Only). Israel; 2016. Available online: https://www.gov.il/he/departments/policies/2016_des1403 (accessed on 27 September 2017).

15. Israel Union for Environmental Defense. Living in Junk: Waste and Recycling in Israel (Hebrew Only). Israel. 2019. Available online: https://www.adamteva.org.il/wp-content/uploads/2019/07/Junk.pdf (accessed on 25 October 2019).

16. Ministry of Environmental Protection. Strategic Plan for Waste Treatment by 2030 (Hebrew Only). Israel; 2018. Available online: https://www.gov.il/he/departments/policies/strategic_plan_for_waste_treatment_by_2030 (accessed on 14 September 2018).

17. Ministry of Environmental Protection. Sources of Water Pollution (Hebrew Only). Israel. Available online: http://www.sviva.gov.il/subjectsEnv/WaterStreams/WaterPollution/Pages/PollutionSources.aspx (accessed on 30 December 2019).

18. Israel Union for Environmental Defense. Israel's Strategic Reserves are in Jeopardy (Hebrew Only). 2018. Available online: https://www.adamteva.org.il/israels-strategic-reserves-are-in-jeopardy (accessed on 30 December 2018). 
19. Ministry of Environmental Protection. Ministry Functions Regarding the Prevention of Water and River Pollution (Hebrew Only). Israel. Available online: http://www.sviva.gov.il/subjectsEnv/WaterStreams/ WaterPollution/MOEPolicyWaterPollution/Pages/default.aspx (accessed on 30 December 2017).

20. Friman, H.; Sitbon, Y.; Banner, I.; Shauli, Y.; Einav, Y. Renewable Energy, Ecology and Environment to Arabic Pupils Using a Creative "Hands On" Approach. Environments 2018, 5, 66. [CrossRef]

21. Caine, R.N.; Caine, G. Education on the Edge of Possibility; Association of Supervision and Curriculum Development: Alexandria, VA, USA, 1997.

22. Lewis, L.H.; Williams, C.J. Experiential Learning: Past and Present. New Dir. Adult Contin. Educ. 1994, 62, 5-16. [CrossRef]

23. Itin, C.M. Reasserting the Philosophy of Experiential Education as a Vehicle for Change in the 21st Century. J. Exp. Educ. 1999, 22, 91-98. [CrossRef]

24. McDonough, D. Similarities and Differences between Adult and Child Learners as Participants in the Natural Learning Process. Psychology 2013, 4, 345-348. [CrossRef]

25. Beard, C.; Wilson, J.P. The Power of Experiential Learning: A Handbook for Trainers and Educators; Kogan Page: London, UK, 2006.

26. Kolb, D.A. Experiential Learning: Experience as the Source of Learning and Development; Prentice-Hall: Englewood Cliffs, NJ, USA, 1984; p. 26.

27. Coffield, F. Learning Styles and Pedagogy in Post-16 Learning: A Systematic and Critical Review; LSRC reference; Learning \& Skills Research Centre: London, UK, 2004.

28. Molina-Motos, D. Ecophilosophical Principles for an Ecocentric Environmental Education. Educ. Sci. 2019, 9, 37. [CrossRef]

29. Wallach, A.D.; Batavia, C.; Bekoff, M.; Alexander, S.; Baker, L.; Ben-Ami, D.; Boronyak, L.; Cardilini, A.P.; Carmel, Y.; Celermajer, D.; et al. Recognizing animal personhood in compassionate conservation. Conserv. Biol. 2020, 34, 1097-1106. [CrossRef] [PubMed]

Publisher's Note: MDPI stays neutral with regard to jurisdictional claims in published maps and institutional affiliations.

(C) 2020 by the authors. Licensee MDPI, Basel, Switzerland. This article is an open access article distributed under the terms and conditions of the Creative Commons Attribution (CC BY) license (http://creativecommons.org/licenses/by/4.0/). 